九州大学学術情報リポジトリ

Kyushu University Institutional Repository

Redescriptions of the Types of Some Japanese Scelionidae Preserved in the United States National Museum (Hymenoptera, Proctotrupoidea)

Hirashima, Yoshihiro

Entomological Laboratory and Hikosan Biological Laboratory, Faculty of Agriculture, Kyushu University

Yamagishi, Kenzo

Entomological Laboratory and Hikosan Biological Laboratory, Faculty of Agriculture, Kyushu University

https://doi.org/10.5109/23726

出版情報：九州大学大学院農学研究院紀要. 25 (4)，pp. 153-159，1981-04. Kyushu University バージョン：

権利関係 : 


\title{
Redescriptions of the Types of Some Japanese Scelionidae Preserved in the United States National Museum (Hymenoptera, Proctotrupoidea)*
}

\author{
Yoshihiro Hirashima and Kenzou Yamagishi \\ Entomological Laboratory, Faculty of Agriculture, \\ Kyushu University 46-01, Fukuoka 812
}

(Received December 2, 1980)

\begin{abstract}
The types of Dissolcus japonicus Ashmead, Telenomus hakonensis Ashmead, Telenomus nawai Ashmead and Telenomus poeta Girault are redescribed. Asolcus plautiae Watanabe is proposed as a synonym of Dissolcus japonicus Ashmead, which is now recognized as Trissolcus japonicus (Ashmead).
\end{abstract}

By the courtesy of Dr. A. S. Mencke, Systematic Entomology Laboratory, USDA, we were able to examine the type specimens of Dissolcus japonicus Ashmead, which is now known as Trissolcus japonicus (Ashmead), Telenomus hakonensis Ashmead, Telenomus nawai Ashmead and Telenomus poeta Girault. Redescriptions of these types are presented in this paper.

We are very grateful to Dr. A. S. Mencke for the loan of the types of these species.

\section{Trissolcus japonicus (Ashmead)}

(Figs. 1-3)

Dissolcus japonicus Ashmead, 1904, J. New York Ent. Soc., 12 (2) : 73. Hakone, Japan.

Trissolcus japonicus: Masner and Muesebeck, 1968, U. S. Nat. Mus. Bull., 270: 72.

New combination.

Asolcus plautiae Watanabe, 1954, Trans. Shikoku Ent. Soc., 4 (2): 18. Female and male. Shikoku. New synonymy.

Holotype female: Length about $1.5 \mathrm{~mm}$, robust.

Black, except as follows: mandibles red; antennae dark reddish brown, partly yellowish; tarsi, apices of tibiae, and trochanters yellow; tibiae reddish brown; coxae piceous.

Head rather large, a little broader than thorax; frontal depression and frontal area near to it transversely wrinkled; median portion of frons distinctly shining, without reticulation; paraocular areas and upper portion of head

* Contribution from the Entomological Laboratory, Faculty of Agriculture, Kyushu University, Fukuoka (Ser. 3, No. 85). 


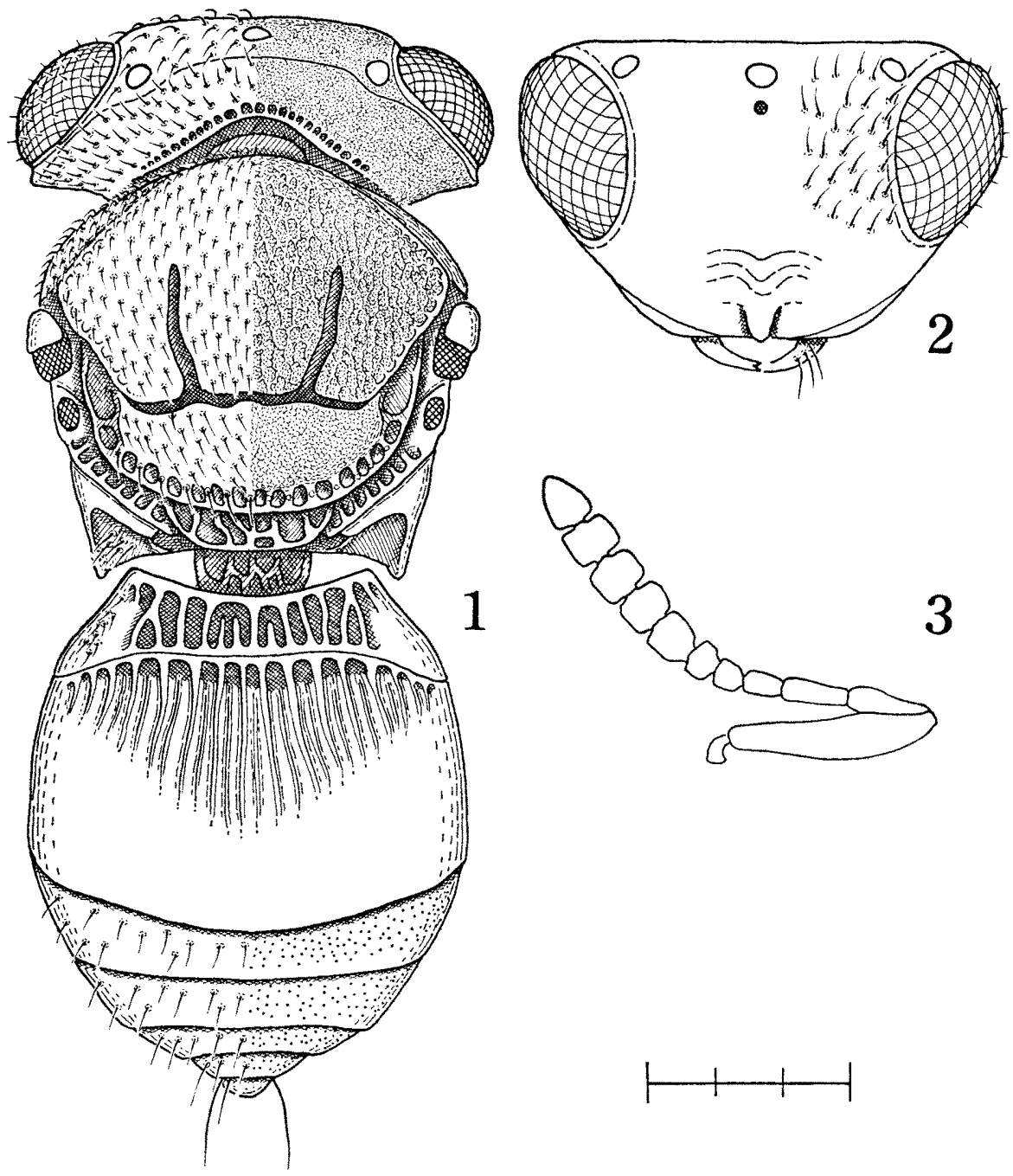

Figs. 1-3. Trissolcus japonicus (Ashmead), female. 1: Dorsal view. 2: Frontal view of head. 3: Antenna. (One scale $0.1 \mathrm{~mm}$ )

distinctly reticulate or minutely roughened, nearly dull; vertex well convex, transversely sharply carinate; anterior ocellus well separated from preoccipital carina, with a frontal pit large; space behind preoccipital carina steep, densely reticulate; ocellar triangle obsolete, anterior ocellus not separated from post-ocellar line; head, as seen from above, latero-posterior corner angulate; eyes bare $(\times 64)$. Antennae 11-segmented; club more or less well formed; terminal antennal segment small, conical; 1 st flagellar segment distinctly elongate, longer than long pedicel; 2nd flagellar segment longer than broad. 
Thorax very strongly convex dorsally; mesoscutum with distinct notauli, distinctly elevated and angulate midanteriorly; mesoscutum with roughened micro-sculptures becoming weaker toward scutellum; the latter well convex, weakly reticulate or nearly smooth as in posterior portion of mesoscutum, shining.

Metasoma a little longer than thorax, broad, broadly flat dorsally; 1 st tergum longitudinally distinctly carinate on interior; 2nd tergum broader than long, well shining, carinate and excavated basally; 3rd and following terga rather broadly exposed, minutely punctate.

Note: This species was described from a single female specimen taken by A. Koebele at Hakone. Type No. 2127, USNM.

This is a distinctive species easily recognizable by the characters of head and metasoma. Masner and Muesebeck (1968) remarked as "unique".

Asolcus plautiae Watanabe is treated as a synonym of Trissolcus japonicus (Ashmead). In this species, the antennae are variable in coloration. They are sometimes broadly blackish. Watanabe described as "Antennae darkbrown to black; scape at the base and pedicel tinged with yellowish-brown".

\section{Telenomus hakonensis Ashmead}

(Figs. 4-6)

Telenomus hakonensis Ashmead, 1904, J. New York Ent. Soc., 12 (2) : 73. Hakone, Japan.

Telenomus hakonensis: Masner and Muesebeck, 1968, U. S. Nat. Mus. Bull., 270: 65. Lectotype designation.

Lectotype female: Length about $1.4 \mathrm{~mm}$, more or less robust species.

Black, except as follows: mandibles yellowish; antennae brownish, scape brownish yellow; legs yellow with coxae yellowish brown. Wings very slightly yellowish subhyaline.

Head rather large, a little broader than thorax, well convex in front in outline when seen from above; eyes densely hairy, rather large, posterior halves of their inner margins considerably diverging posteriorly as seen from above; head distinctly angulate postero-laterally as seen from above; upper portion of head (including space lateral to anterior ocellus) distinctly reticulate; frontal area in front of anterior ocellus smooth, shining. Antennae 11segmented; 1st flagellar segment distinctly elongate, much longer than pedicel which is also much longer than broad; antennal club not distinctly formed; terminal antennal segment longer than broad, subconical with pointed apex.

Mesoscutum without notauli, coarsely sculptured; scutellum slightly convex, nearly smooth, shining, with sparse, microscopical punctures.

Metasoma characteristic in outline, as shown in Fig. 4, broadest beyond middle; 2nd tergum very large, only slightly convex dorsally, smooth, very shining, with longitudinal wrinkles basally; 3rd and following terga very short, total length of them also very short, about as long as 1st tergum. 


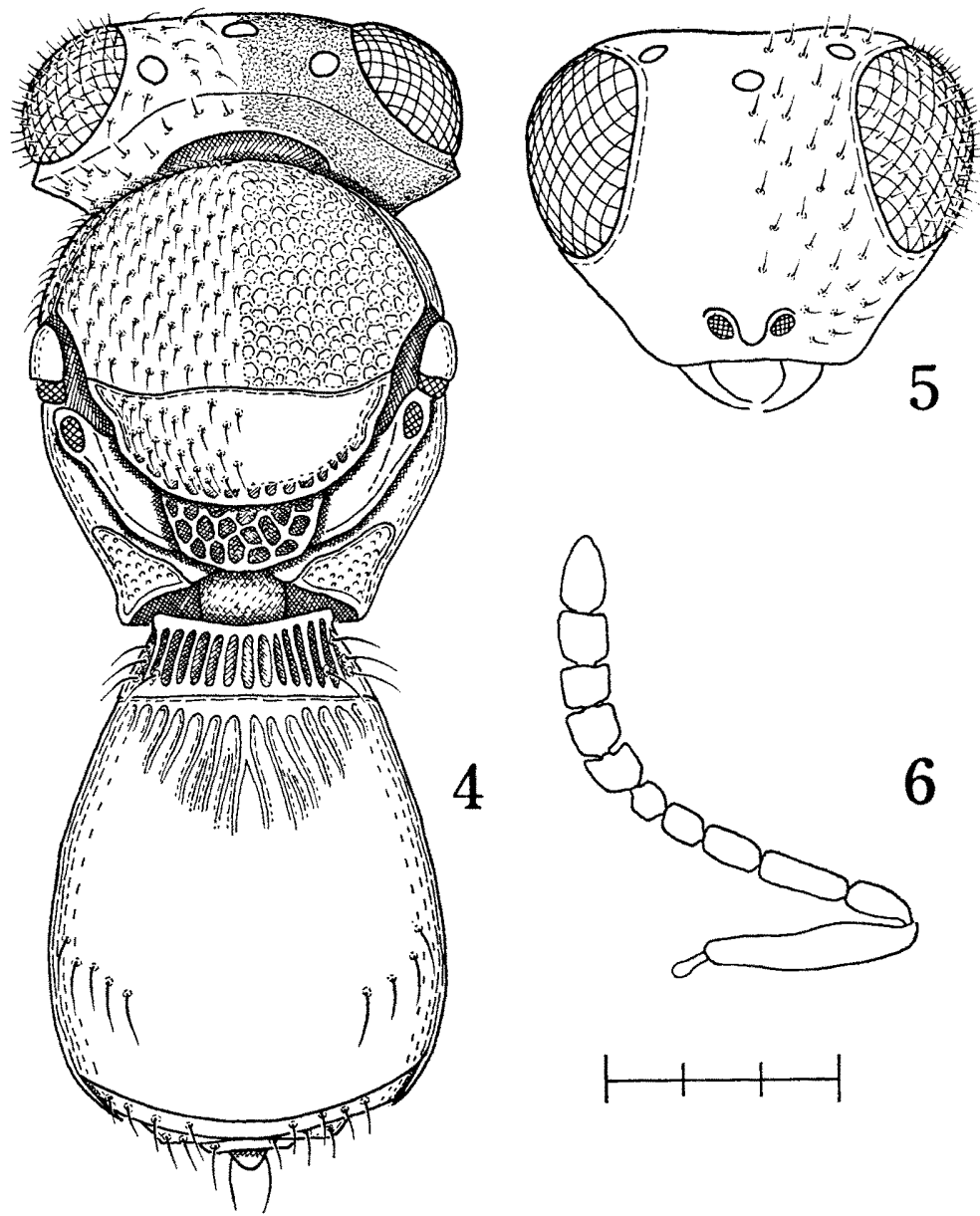

Figs. 4-6. Telenomus hakonensis Ashmead, female. 4: Dorsal view. 5: Frontal view of head. 6: Antenna. (One scale $0.1 \mathrm{~mm}$ )

Note: This species was described from 2 female specimens taken at $\mathrm{Ha}$ kone by A. Koebele. Type No. 7125, USNM. The lectotype was designated by Masner and Muesebeck in 1968. According to them, the cotype female is missing.

Telenomus nawai Ashmead

(Figs. 7-9)

Telenomus nawai Ashmead, 1904, J. New York Ent. Soc., 12 (2) : 72 . Gifu, Japan. Telenomus nawai: Masner and Muesebeck, 1968, U. S. Nat. Mus. Bull., 270: 67. Lectotype designation. 


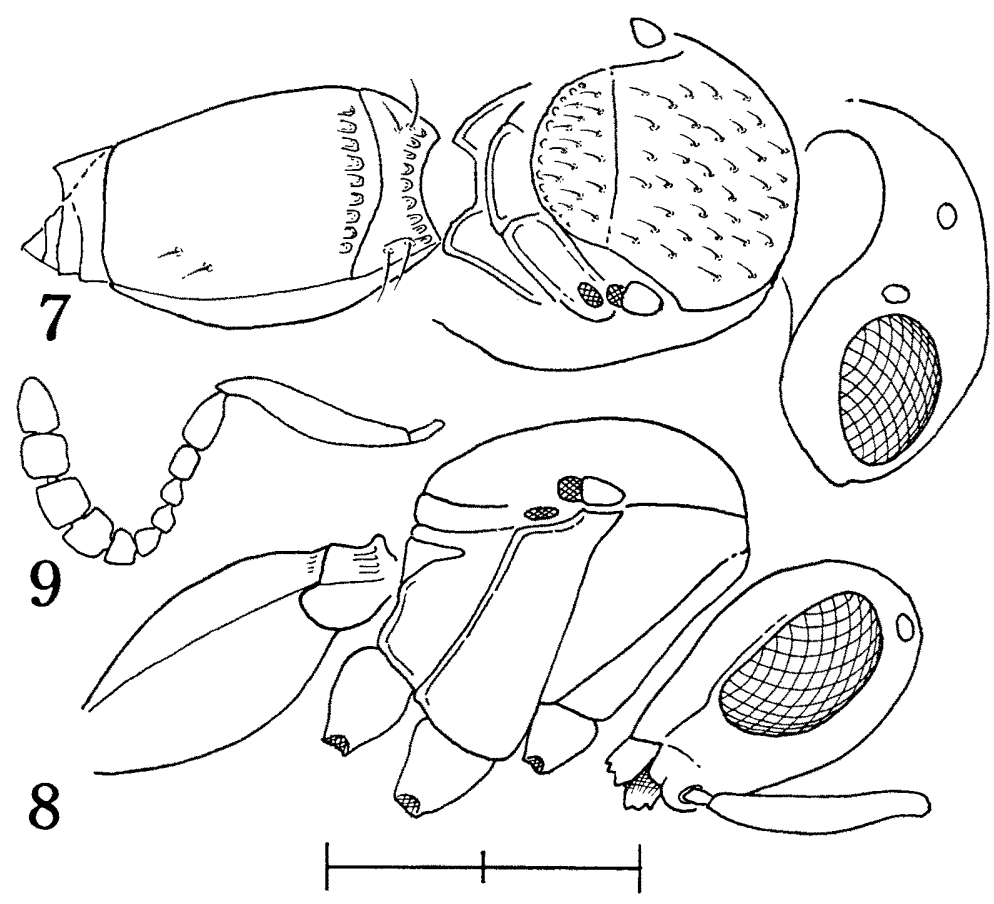

Figs. 7-9. Telenomus nawai Ashmead, female. 7: Dorso-lateral view. 8: Lateral view. 9: Antenna. (One scale $0.1 \mathrm{~mm}$ )

Lectotype female: Head slightly separated from thorax, therefore head measurements not available because of its position.

Length about $0.57 \mathrm{~mm}$ (thorax plus metasoma, $0.47 \mathrm{~mm}$ ).

Piceous, slightly brownish on head and metasoma (black in original description); mandibles yellowish, much paler than lower part of head; antennae brownish; legs brownish, with apices of tibiae and all tarsi whitish except for claw-segments and claws brownish.

Antennae 11-segmented; apical 5 segments forming a distinct club $(\times 100)$; pedicel about or slightly less than twice as long as broad; next 4 segments small and moniliform. Eyes not hairy. Head smooth, shining, impunctate except for very small, not dense, very shallow punctures on latero-apical portions of face $(\times 100)$. Mesoscutum without notauli, not smooth, finely tessellate; sides of thorax finely sculptured except for mesopleuron glabrous. Metasoma about as long as thorax; 1st tergum very short, distinctly sculptured; 2nd tergum large (probably longer than broad), more than twice as long as following terga taken together, slightly convex dorsally, smooth, very shining, with a transverse row of small punctures at extreme base.

The lectotype female is mounted by its side on a card on which 4 cotype males are also mounted.

Male: About as large as female. 
Very similar to female except as follows: More brownish; antennae 12segmented, with moniliform flagellum; legs (including coxae) pale yellowish except for apices of tarsi brownish; metasoma shorter than thorax, with 2nd tergum often concave dorsally ( 3 out of 4 specimens).

The description of the male head is given below.

Head broader than thorax as seen from above; eyes very broadly separated, distance between them about as long as distance between tegulae, about twice as long as eye as seen from above; posterior ocellus very close to eye; head more or less thick as seen from above, with posterior margin emarginate; preoccipital carina absent, and posterior portion of head rounded; vertex broadly convex, with sparse, very fine punctures and with very short pale hairs $(\times 100)$.

Note: This species was described from 18 specimens (both sexes) bred by Mr. N. Nawa from the eggs of an unknown Lepidopteron. Type No. 7123, USNM.

\section{Telenomus poeta Girault}

(Figs. 10-12)

Telenomus poeta Girault, 1920, Proc. U. S. Nat. Mus., 58: 178. Central Japan.

Telenomus poeta: Masner and Muesebeck, 1968, U. S. Nat. Mus. Bull., 270: 69. Lectotype designation.

Lectotype female: Length about $1.2 \mathrm{~mm}$, more or less robust.

Black, except as follows: mandibles reddened apically; antennae piceous; legs piceous with paler portions (in cotype female, both extremities of tibiae pale brownish, and tarsi pale brownish with a few apical segments brownish); metasoma nearly piceous. Wings subhyaline.

Head, as seen from above, a little broader than thorax, slightly more than twice as broad as long (about 18:7); interocular distance not very long, 1.5 times as long as eye as seen from above; head with portion behind eye well developed, more or less angulate, broadly rounded in outline as seen from above; vertex well convex, slanting behind; ocelli very small; ocellar triangle well noticeable, anterior ocellus in front of line tangential to anterior margins of posterior ocelli; as seen in front, inner eye margins distinctly converging above; head below eyes distinctly receding as seen in front; frons well convex, broadly rounded, smooth and shining; region of antennal base broadly concave; paraocular areas very slightly tessellate, upper portion of head (interocular space including vertex) distinctly tessellate, weakly shining. Eyes with dense, minute, whitish hairs.

Metasoma about as long as thorax, slightly broader than the latter; 2nd tergum about as long as broad, much more than twice as long as following terga taken together, more or less well convex dorsally, smooth, very shining, with longitudinal wrinkles basally. 


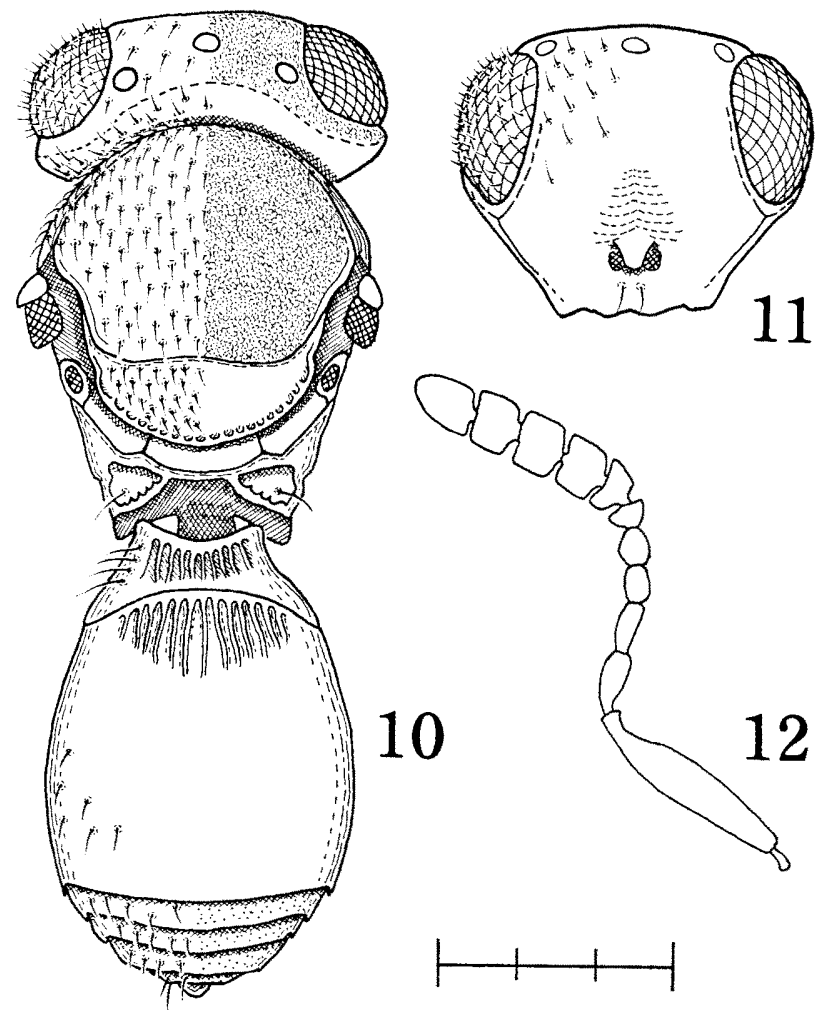

Figs. 10-12. Telenomus poeta Girault, female. 10: Dorsal view. 11: Frontal view of head. 12: Antenna. (One scale $0.1 \mathrm{~mm}$ )

Note: Originally described from 3 females, one of which was designated as the lectotype by Masner and Muesebeck in 1968. Central Japan, from the eggs of Dictyoploca japonica (Moore). Type No. 20604, USNM.

This is a rather large, more or less robust species which is easily known by the head being transverse and rounded in outline as seen from above.

\section{REFERENCES}

Ashmead, W. H. 1904 Descriptions of new Hymenoptera from Japan-I. J. New York Ent. Soc., 12 (2): 65-84

Girault, A. A. 1920 New serphidoid, cynipoid, and chalcidoid Hymenoptera. Proc. U. S. Nat. Mus., 58: 177-216

Masner, L. and C. F. W. Muesebeck 1968 The types of Proctotrupoidea (Hymenoptera) in the United States National Museum. U. S. Nat. Mus. Bull., 270: 1-143

Watanabe, C. 1954 Discovery of four new species of Telenominae, egg-parasites of Pentatomid and Plataspid bugs, in Shikoku, Japan (Hymenoptera: Proctotrupoidea). Trans. Shikoku Ent. Soc., 4 (2): 17-22 